DOI https://doi.org/10.32837/app.v0i67.1165

UDC 327

N. O. Konopka
orcid.org/0000-0002-1245-3459
PhD. in History Asociate Professor

Ph.D. in History, Associate Professor,

Associate Professor at the Department of International Relations

National University of Ostroh Academy

T. L. Strykhotskyi

orcid.org/0000-0001-6978-8076

Master of International Relations

National University of Ostroh Academy

\title{
CULTURAL DIPLOMACY OF THE KINGDOM OF SAUDI ARABIA IN THE CONTEXT OF THE VISION 2030 STRATEGY IMPLEMENTATION
}

Emphasis on the problem. Given the new challenges the Kingdom of Saudi Arabia is facing now, positioning in the international arena becomes a matter of great importance for this state. During the security, energy, migration as well as diplomatic crises, and the information and communication revolutions, on their background, Riyadh is trying to apply new approaches in its foreign policy and form a new paradigm of cultural policy and diplomacy within the obscure and transforming international environment. Hence, at both regional and global levels, the Kingdom of Saudi Arabia is implementing soft power tools in general and cultural diplomacy in particular, trying to take full advantage of the modern achievements of the information age.

Analysis of the latest research and publications. Predominately, the works of non-Ukrainian researchers are devoted to the analysis of the peculiarities of the formation and application of new approaches to Saudi Arabia's cultural diplomacy. Abdullah Khuliyf A. Alanazi focuses his research on the policy of using the Kingdom's soft power instruments in the context of the Saudi-Iranian confrontation (Alanazi, 2015). Abdulilah R. Alkatheeri and Muhammad Khan from the International Islamic University (Islamabad, Pakistan) outline the peculiarities of the formation and prospects of the soft power of the Saudi monarchy, emphasising the crucial role in the reform processes in the economy, health, education, social, transport, agricultural, water supply and industrial sectors of King Abdullah and his successor King Salman (Alkatheeri, Khan, 2019). Hasan Ismaik's publication in Al Arabiya news agency is devoted to the foundations and uniqueness of the Kingdom's soft power (Ismaik, 2020). Saudi political analyst Eklil Badr Sallam summaries the Kingdom's public diplomacy and its components in her scientific paper (Sallam, 2018). Russian researcher O. Chikrizova in the article Saudovskaya model razvitiya dlya Mira islama: osobennosti i ogranicheniya (The Saudi Model of Development for Islamic World: The Peculiarities and Limits) analyses the main aspects of religious diplomacy of the KSA as one of the main components of Riyadh's foreign policy (Chikrizova, 2019). Analytical and news materials are published by both regional (Arab News, Saudi Press Agency (SPA), Saudi Gazette, The National News, Al Arabiya), and foreign media (Al-Monitor, BBC News, Reuters, The Art Newspaper, etc.).

The Vision 2030 and Cultural Vision strategies, outline the features and prospects for the development of Saudi Arabia's soft power for the next decade, are essential for the analysis of soft power and cultural diplomacy. Official websites of the Saudi government, institutions, and organizations of the Kingdom are important information sources.

The current article aims to analyze the peculiarities of cultural diplomacy of the Kingdom of Saudi Arabia in the context of its implementation of the Vision 2030 strategy.

Presentation of the general material. In recent decades, the role of soft power, as well as public and cultural diplomacies, has drastically increased. Interdependence has reached its historical significance, and the development of the world's communications only accelerates the transition from R. Aron's "soldier-diplomat" to J. Rosenau's "tourist-terrorist" world. The promotion of culture gives states a credit of trust to their actions in the eyes of other societies, which is vital to maintain the foreign policy course in the era of high-speed Internet and messengers. 
The international non-profit organization Institute for Cultural Diplomacy (ICD) defines cultural diplomacy as "actions based on the exchange of ideas, values, traditions and other aspects of culture and identity to strengthen relations, expand socio-cultural cooperation and promote national interests in the country and beyond, which can be carried out by the state, private sector or civil society" (Institute of Cultural Diplomacy). The Institute identifies five key principles of cultural diplomacy:

- recognition of and respect for cultural diversity and heritage;

- global intercultural dialogue;

- protection of international human rights;

- justice, equality, and interdependence;

- global peace and stability (Institute of Cultural Diplomacy).

Polish researcher Anna Umińska-Woroniecka, exploring the place of cultural diplomacy in the context of the analysis of three main schools of international relations and the theory of diplomacy, determines political neorealism as the least "favourable" to cultural diplomacy. Political realists believe that cultural diplomacy has no direct impact on the state's strength nor defines a country's place in the international system and can be ignored as a result. On the other hand, the school of political neoliberalism and American researcher Joseph Nye, who coined the term "soft power" in opposition to the realistic "sharp power", proves to be most "committed" to cultural diplomacy. Examining the place of cultural diplomacy in the theory of diplomacy, the author concludes that cultural diplomacy has been marginalised for a long period of world history, but today it is one of the key tools for influencing the international arena (Uminska-Woroniecka, 2016). Slovak scholar Erik Pajtinka in his work Cultural Diplomacy in the Theory and Practice of Modern International Relations analyses the history and definition of the term "cultural diplomacy" and identifies the main functions of cultural diplomacy carried out by governmental agencies, including:

- promotion of national culture and language;

- dissemination of cultural values;

- agreement conclusions on cultural cooperation;

- work with ex-pats (Pajtinka, 2014).

According to H. Ismaik, the soft power of Saudi Arabia has four unique characteristics that are combined only in the Kingdom. In particular, it is the centre of Islam and the Arabs, as well as the balance in international relations. The fourth characteristic is Crown Prince Mohammed bin Salman and his views of the state's future progress (Ismaik, 2020). The main task of KSA public diplomacy is to build international bridges. Today, Riyadh uses several public diplomacy components, such as cultural diplomacy, educational exchange programs, and international broadcasting. The Kingdom promotes its foreign policy interests using a unique approach that involves the use of both hard and soft power. This approach is directly related to the fact that Saudi Arabia is the birthplace of Islam and is one of the world's richest countries with enormous oil reserves (Sallam, 2018).

The importance of cultural diplomacy for improving the international image and development of strategic communications is recognised by the current leadership of Saudi Arabia, which has launched a strategy of cultural "discovery" of the state at various levels (Saudi Cultural office in Vienna, 2019). The assassination of J. Hashoggi, the humanitarian crisis in Yemen, human rights abuses, and the persecution of activists have severely damaged the Kingdom's reputation. According to Rehan Ismail, an analyst at the Centre for Arab and Islamic Studies at the National University of Australia, Riyadh has spent millions of dollars to ameliorate its image in the West, especially after the murder of the journalist (Free tourist trips..., 2019). For example, in Australia, KSA enlisted the informational support of famous people who actively disseminated photo and video content on social networks about Saudi Arabia as a unique tourist country.

The fundamental documents of the KSA, adopted in the new conditions and vital for the analysis of the components of the monarchy's soft power are the Vision 2030 (2017) and Cultural Vision (2019) strategies, which outline the directions of future transformations in the soft power of Saudi Arabia. Thus, the process of reform and transformation, which takes place under the auspices of the state, launched a modern renaissance of Saudi culture, which will play a major role in the process of economic diversification and is a central element of Saudi identity and history. 
Undoubtedly, religion is an integral part of Saudi culture and self-identity. On the Kingdom's territory, there are two sacred to the entire Muslim community cities, which are the centres of world Islam. Saudi Arabia receives more than two million pilgrims each year and, importantly, political leaders from around the Muslim world. Thus, the country not only represents its culture to millions of pilgrims but also has the opportunity to maintain contacts at the level of senior management. At the same time, it imposes certain restrictions on Saudi foreign policy that require manoeuvring between the positions of all states with a predominantly Muslim population.

The importance of the religious factor led to the establishment of the Ministry of Islamic Affairs, Dawah and Guidance. The purpose of the Ministry is to promote the Holy Quran and Islam among the people of KSA and abroad. Under the Ministry's direct authority, the King Fahd Glorious Quran Printing Complex was established to carry out part of these duties. The Ministry also facilitates competitions to study the Holy Quran and the Sunnah, takes care of Islamic centres and mosques, supports and assists Islamic communities, coordinates Islamic organization s' activities, and bolsters Islamic universities and institutes abroad (Ministry of Islamic Affairs). The heads of the Ministry of Islamic Affairs, Dawah and Guidance and the Supreme Mufti have traditionally been members of the Al-Sheikh family, who are long-time allies of the Al-Saud family. The head of the Ministry is Abdul Latif bin Abdulaziz bin Abdulrahman Al-Sheikh.

One of the fundamental pillars of Saudi cultural diplomacy is book printing, coordinated by the Complex for the publication of the Holy Quran named after King Fahd in Medina (Alanazi, 2015). This institution reaffirms the Kingdom's leadership position in world Islam and Saudi monarchs' reputation as Custodians of the Two Holy Mosques. Each year, the Complex publishes millions of copies of the Quran in various languages, which are edited by Saudi theologians. Texts, printed under Complex auspices, are used in many countries with numerous Muslim sects and their branches. In addition to book publishing, the Complex staff digitises the texts of the Quran and creates audio copies for further distribution. More than 323,5 million copies of various editions of the Muslim holy book have been published by the Complex, since its founding in 1985, according to the Saudi News Agency (King Fahd Complex for Printing, 2020). In 2018 alone, the Complex printed more than 18 million copies of the Holy Quran (King Fahd Glorious Quran).

Saudi Arabia participates in book fairs, which take place in Asian and African countries. These events are actively covered by the state media, as the KSA is traditionally one of the countries with the highest percentage of readers and educated people. In 2019, Saudi Arabia took part in the 50th Cairo International Book Fair, one of the world's biggest book fairs in the Arab world and beyond. According to the Cultural Attaché of Saudi Arabia, the purpose of the KSA's participation in this event was to present scientific and cultural progress, economic and urban development in the context of Vision 2030. The Kingdom had the largest book pavilion, which featured both public and private publishers, public and university libraries, and others (Saudi Pavilion, 2019). A wide cultural program was also organised, including an exhibition of works of art. In addition to media coverage, regional and international book fairs are supported at the state level. Ambassadors and representatives of Saudi diplomatic missions are frequent guests at foreign book fairs, while heads of provinces and state officials are usually guests at domestic ones.

The King Abdullah bin Abdulaziz International Centre for Interreligious and Intercultural Dialogue, KAICIID, is a key Saudi initiative that fosters intercultural dialogue since 2012. Then UN Secretary-General Ban Ki-moon welcomed the Centre's creation by saying, "I fully support your vision of religion as a means of mutual respect and reconciliation" (Heneghan, 2012). The purpose of the organization, funded by the governments of Spain, the Vatican, and Saudi Arabia, is to establish interfaith dialogue in various countries of the world. With the support of KAICIID, there was established Muslim-Jewish Leadership Council, which brings together Jewish and Muslim religious leaders from European states. KAICIID also took part in creating initiatives for religious reconciliation in Myanmar, Nigeria, and the Central African Republic (Annual report, 2019, p. 3). Besides, the Centre deals with the issues of social adaptation of Muslim refugees who left their states due to hostilities. KAICIID cooperates with the Organization of Islamic Cooperation and the Islamic Organization for Education and Culture (Chikrizova, 2019, p. 554). In 2019, KAICIID was admitted to the Group of Friends of the Alliance of Civilizations and supported the development of an Action Plan for the 
Protection of UN Religious Sites, developed under the leadership of the UN Secretary-General (Annual report, 2019, p. 7). According to the Supervisor General of the Centre, Faisal bin Abdulrahman bin Muaammar, "the potential of religious organizations as partners for policymakers remains largely underestimated" (Snell, 2020). Hence, the Kingdom will use the religious factor in the future to promote its interests in the Arab, Muslim, and global world.

As mentioned above, the most important document designed to make Saudi Arabia attractive to the world through soft power is the Vision 2030 strategy, which the Crown Prince introduced in 2017. Along with economic and governance reforms, Vision 2030 focuses on the cultural power of Saudi Arabia as the heart of the Arab as well as Islamic worlds. The leaders of the Kingdom plan to carry out a large-scale reform in culture and make full use of the tourist power of the state (Konopka, Strykhotskyi, 2020, p. 105).

In order to implement a systemic state policy in the field of culture in the context of the Vision 2030 strategy, the Ministry of Culture was established and began its work in March 2019. The Ministry's website states that it plays a central role in each of the three pillars of Vision 2030: the formation of a dynamic society, a prosperous economy, and an ambitious nation (The Ministry of Culture). To this end, 11 special commissions have been set up within the Ministry, each of which is responsible for one of the areas of the cultural sphere, in particular: fashion, cinema, museums, culinary arts, etc. (Althari, 2021).

On the first day of work, the Ministry published a document entitled Cultural Vision. The document defines the goals of the Ministry that include "creating opportunities for culture to contribute to the country's economy" and "creating opportunities for global cultural exchange" (Our Cultural Vision, 2019). It is essential because Saudi reforms provide for significant liberalisation of human rights and freedoms in order to increase the contribution of civil society to the country's economy and, at the same time, maintain its current insignificant influence on the political leadership of the KSA. Also, the authors of Cultural Vision see culture as the central component of all international visits. The Ministry planned to showcase its first achievements at the G-20 summit in Riyadh in 2020; however, due to the coronavirus pandemic, the meeting of world leaders took place on a virtual basis and was entirely focused on the fight against Covid-19 and its consequences. Another event that was planned to effectively demonstrate the achievements of implementing the Cultural Vision strategy was Expo 2020 in the UAE (Our Cultural Vision, 2019, p. 20), but it was also postponed to 2021. The Ministry is led by Prince Badr bin Abdullah bin Mohammed bin Farhan al-Saud, a close political ally of Crown Prince Mohammed bin Salman.

In the summer of 2018, Saudi Arabia participated for the first time in the Venice Architecture Biennale (Konopka, Strykhotskyi, 2020, p. 105) and the Cannes International Film Festival, which were used as platforms to increase international interest in the prospects of the Saudi film and television industry (Mogielnicki, 2018). According to the Ministry of Culture, a crucial role in the country's cultural development should be played by cinema. In April 2018, for the first time in 35 years, the Marvel film Black Panther was shown in the Kingdom. Moreover, in March of the same year, the Council for Cinematography was established within the Ministry of Culture. Concurrently, the development of this sphere is connected with state censorship and state intervention in the media sphere. Since its inception, the Ministry has joined two programs to develop Saudi cinema: Daw Film Directors Competition, which aims to support local filmmakers (Daw film, 2019), and the internship program for young directors at the world's best universities (Filmmakers, 2020). In early 2021, the Saudi State Cinematographic Commission signed cooperation agreements with 28 directors who won the Daw competition and signed contracts worth more than \$ 10 million (Saudi Film, 2021). The commission will collaborate with directors in screenwriting films and producing feature films. Furthermore, the Saudi film Scales won the Verona Film Festival Award in the Innovative Category (Saudi-directed film, 2019).

In early 2021, the Ministry of Culture established the Cultural Development Fund (CDF), which is linked to the National Development Fund (NDF) and is designed to promote the development and transformation of various cultural sectors within the Vision 2030 (Saudi Culture Minister, 2021). According to CDF leader Badr bin Hussein Al-Zahrani, every effort is being made to promote Saudi art and culture, which will increase GDP by about $\$ 1.2$ billion (Steps, 2021). 
At the same time, the Ministry of Culture has implemented some initiatives that stimulate Saudi art development, support artists and promote global cultural exchange. One of the first initiatives represented in 2019 was "cultural residence": Saudi Arabia offered to grant the right to permanent residence in the Kingdom for foreign artists (Radwan, Tashkandi, 2019). In January 2020, an Al-Balad Art Residence Project was announced in Jeddah; it is open to both Saudi and foreign artists, writers, and cultural managers. For six weeks, the artists were able to work on their own project under the auspices of Athr Gallery, one of the Kingdom's leading contemporary art galleries. Back in 2019, under the auspices of the gallery, Saudi artists had the opportunity to meet with their colleagues in New York, Paris, Barcelona, and Beirut (Chaves, 2020). In addition, it provides for the provision of scholarships, awards, and the creation of a cultural fund (created in early 2021 - NK, TS) to support artists, the fashion sector, and other areas of culture. At the end of 2020, there was announced governmental readiness for implementing the second part of the project Art Residence of Al-Balad for 2021-2022, which will involve both Saudi and foreign artists, critics, researchers, and writers (Saudi Culture Ministry, 2020). In early 2021, the Ministry of Culture of the KSA announced a competition named Marathon of Cultural Initiatives with a prize fund of $\$ 80$ thousand, which is part of the Quality of Life Program, aimed at achieving the goals of the Vision 2030 strategy. During this marathon, the Centre for Cultural Initiatives was launched, aiming to stimulate the development of various culture sectors and the generation of creative ideas (Saudi Arabia opens, 2020).

Since 2019, Saudi Arabia has opened to tourists and plans to invest $\$ 64$ billion in the entertainment industry's development over the next decade (Saudi Arabia to invest, 2018), but the pandemic has made its adjustments in this sector as well. In an interview with the Arab News, the Minister of Tourism of the Kingdom Ahmed al-Khateeb said that Saudi Arabia is on track to achieve its ambitious goal - to reach 100 million tourists per year by 2030 (Frankly Speaking, 2020), of which 36 million should be religious tourists ( 6 million during the Hajj and 30 million during the small pilgrimage - Umrah) (Umrah, 2020). Unfortunately, due to the coronavirus crisis in 2020, a number of restrictions were imposed on a religious pilgrimage and the tourism industry as a whole. Most restrictions still apply today. Moreover, the KSA tourism sector expects \$ 200 billion in investment income by 2030. The government hopes that the tourism industry's revenues will reach $10 \%$ of annual GDP by 2030, compared to 3\% today, and will create more than 1 million jobs. To achieve these ambitious goals, the government has adopted the National Tourism Strategy, which should unleash the powerful tourism potential of the Kingdom. The first phase of the strategy is creating the Tourism Development Fund (Fahy, 2020), which provides an increase in foreign investment, the search for international partners, effective strategic communication.

Furthermore, the Ministry of Culture plans to expand the country's network of museums, as this will attract tourist flows. In December 2020, Laila Alfaddagh, a well-known museum specialist, was appointed to the position of director-general of the National Museum of the Kingdom. She played a key role in creating a children's museum in the monarchy, founded the Ithra Art Prize and contributed to the launch of the Art Cafe program (a project of the Saudi Aramco energy company) (Laila Alfaddagh, 2020).

By 2023, a unique museum of modern digital art, called TeamLab Borderless Jeddah, will be built in Jeddah by the Japanese company TeamLab. This museum will be the fourth worldwide after similar interactive museums in Tokyo, Shanghai, and Macau. The museum's opening is part of a campaign to promote Saudi Arabia's cultural values, which allows it to diversify its economy and create a more "open image" of the country in the context of Vision 2030 (Harris, 2020). The idea of creating a museum is in tune with other special cultural events, including the Desert X Sculpture Exhibition, which opened in the Al-Ula region of north-western Saudi Arabia in early 2020.

In April 2020, the Dar Al-Qalam calligraphy centre in Medina was renamed after the Crown Prince Mohammed bin Salman. Now, The Prince Mohammad bin Salman Global Centre for Arabic Calligraphy contains a museum, an exhibition hall, and an institute dedicated to the art of Arabic calligraphy. Under the royal decree, the Ministry of Culture will oversee the Centre's work with the Royal Foundation for Research and Archives to transform the Centre into a global calligraphy platform for scholars from around the world (Tashkandi, 2020a). 
The Ministry of Culture actively uses the latest means of communication in the implementation of cultural diplomacy. In April 2020, the Ministry announced an online platform for the study of Arabic calligraphy by renowned artists (Tashkandi, 2020b). This activity is aimed primarily at the Arabic-speaking audience because the platform works only in this language. Moreover, the Ministry of Culture has initiated the creation of the Cultural Database, which will include professional and personal data of Saudi artists. A single database can facilitate the creation of strategic cultural projects and increase the level of communication between the Ministry and artists (Ministry of Culture Launches, 2020).

The MiSK Art Institute (MAI) was founded in 2017. The head of the Institute is the famous Saudi artist Ahmed Mater, and the chairman of the board is Crown Prince Mohammed bin Salman. The MAI was created to support Saudi artists and promote cultural diplomacy and exchange. It is headquartered in Riyadh, with offices in London, Venice and Abkha (MiSK Art). The MAI has already begun implementing an international program at the Museum of Contemporary Art in New York; held discussion panels and virtual reality screenings at Art Dubai, the Kennedy Centre in Washington, DC, and the Monde Arabe Institute in Paris. On December 3-7, 2020, the Institute held its fourth MiSK Art Week and launched the first annual grant to support and promote Saudi artists (Works, 2020).

In June 2020, the Saudi government announced plans to launch a new biennale of contemporary art in 2021 and Islamic art in 2022 in the historic site of Ad Diriya on the outskirts of Riyadh. According to the National Newspaper, the 15th-century city of At-Turaif, known as the "pearl of Saudi Arabia" and a UNESCO World Heritage Site, is located in the Ad Diriya area. The city of At-Turaif is a central element of the Kingdom's tourism strategy and rebranding initiative (Harris, 2020), but falling oil prices and a pandemic have delayed cultural events there. Furthermore, by 2022, an oil museum in Riyadh and a Saudi music museum named after Tariq Abdul Hakim in Jeddah will be established.

The leading global structure directly related to soft power is UNESCO. The organization promotes not only educational and scientific cooperation but also supports cultural diversity around the world. Vision 2030 aims to deepen Saudi Arabia's cooperation with UNESCO and double the number of cultural heritage sites in the country, thus increasing the number of jobs. With the establishment of the Ministry of Culture, Saudi Arabia has deepened its cooperation with UNESCO: in 2019, the country was first elected to the organization 's World Heritage Committee. In addition, in 2020, KSA allocated \$ 25 million for projects of the organization that aim for preservation of cultural heritage sites and support of the creative economy (Saudi Arabia commits). Active cooperation with UNESCO can stimulate the development of Saudi science and promote the Kingdom's culture worldwide.

Despite the absolute dominance of the state in Saudi Arabia's cultural diplomacy, there is also a private sector represented by the Al Saud family members. Princes Sultan bin Abdulaziz Al Saud and Alwaleed bin Talal bin Abdulaziz Al Saud play the most prominent roles in promoting Saudi culture. The Prince Sultan Foundation cooperates with several world universities and international organizations to spread knowledge about Islam, the Arabic language, and the state and fights against negative stereotypes about the KSA and Islam (Cultural Communication). Moreover, the Prince Sultan Foundation supports a joint program with UNESCO to promote the Arabic language in which numerous activities are carried out. With the active support of the Foundation, December 18 was recognised as World Arabic Day (Prince Sultan).

While the Prince Sultan Foundation works mainly with organizations and universities, the Prince Alwaleed Foundation promotes Islamic art among Western countries. In 2005, the Foundation allocated \$23 million to establish the Centre for Islamic Art in the Louvre, and in 2019 it financially supported the opening of the Education Centre in its structure. Former President of the French Republic Francois Hollande and Saudi Princess Lamia Bint Majid Al Saud (New spaces, 2019) were present at the opening of the renovated Centre. Furthermore, the Prince Alvalid Foundation is funding the expansion of The Museum of Islamic Art in Berlin.

However, according to experts, due to the coronavirus crisis, falling oil prices, and reduced foreign investment, ambitious Vision 2030 projects will dwindle. Some high-ranking officials in the Middle East claim that the Gulf's economy may never return to pre-crisis conditions; hence political elites are 
taking steps to optimise its current state. This pause will also be a time to reflect on various aspects of Vision 2030 and its timing. According to Scott Livermore, the chief economist at Oxford Economics Middle East, Saudi strategy “was already under review" even before the 2020 crisis (Castelier, 2020).

At the same time, the G20 summit held on November 4, 2020, outlined the results of two years of Saudi cultural reforms. The inclusion to the agenda of the development of culture, among other means of economic regeneration after the pandemic, indicates that the reforms will continue and will have not only a regional but also a global impact. As a result, KSA cultural diplomacy will become a key component of Riyadh's soft power, which will be actively broadcast by regional and global media. At a summit of culture ministers, Saudi Arabia offered a tripartite vision of culture as a way of life, a factor in economic growth, and an opportunity for international exchange. The pace of cultural transformation is evidenced by the fact that in 2019 alone, more than 5,000 books translated into Arabic were published, as well as 161 novels by Saudi writers. Also, 11 universities in the Kingdom opened clothing design programs, 101 films were made, and Saudi theatre figures collaborations with foreign partners received more than 300 international awards, 255 art exhibitions were held, 8 Saudi projects received the international award Aga Khan in the field of architecture, 7 cultural sites of KSA were included in the UNESCO's lists of the intangible cultural heritage. The culmination of these achievements, according to S. Altari, is the launch of the first Saudi Fashion Incubation Program, the granting of the first licenses to two music institutes of the Kingdom, and the election of Saudi Arabia as a member of the UNESCO Committee for Intangible Cultural Heritage (Althari, 2021).

Conclusions. The need for cultural diplomacy has become a modern norm, to which Saudi Arabia is trying to adapt. The kingdom has a powerful tool of soft power, which consists of religious weight, economic power, and a stable political regime, but lacks a cultural factor to attract the societies of developed countries. In recent years, the country has been trying to change the image of a conservative state, but without significant changes in domestic policy.

The status of the KSA as the centre of world Islam allows the country to actively use religion as an integral tool of cultural diplomacy and creates prospects for the development of religious tourism. The policy in this direction is implemented by the Ministry of Islamic Affairs, Dawah and Guidance, which deals with the spread of Islam by supporting Islamic communities, organizations, and educational institutions abroad. The Ministry oversees the printing industry, which allows the Saudi vision of Islam to be represented in most Muslim countries and countries with a significant Muslim population.

Since 2017, the monarchy has been carrying out systemic reforms to implement which the newly created Ministry of Culture plays an important role. Therefore, the Kingdom seeks to make the most of cultural diplomacy tools for positioning in the international arena. Despite the pandemic, Saudi Arabia managed to implement a number of projects in various fields of culture, in particular: the creation of the Cultural Development Fund, the launch of the project Art Residence Al-Balad, online courses in Arabic calligraphy, and others. Cinema and museum work are effective tools for transmitting Saudi values, lifestyles, fine arts, language, and historical heritage to the global level; hence they have become top priority areas of culture.

At the same time, Saudi Arabia has begun to put the cultural sector more actively on its own political agenda. Evidence of this is the creation and operation of KAICIID and the establishment of closer cooperation with UNESCO.

Undoubtedly, an obstacle to the implementation of cultural development programs was the global pandemic COVID-19, which made adjustment to the process of international events and tourism development. It is the pandemic that will determine the scope of the country's cultural diplomacy in the short term, as cultural sector reform could boost the Kingdom's revenue from the non-oil sector and become one of the foundations of Saudi prosperity due to economic diversification. Thus, it is safe to say that the KSA will not only not abandon the chosen path in the field of cultural policy in the context of the implementation of Vision 2030 but also intensify efforts in this direction. This makes the topic promising for further research into cultural diplomacy and the soft power of the Kingdom of Saudi Arabia in general. 


\section{Bibliography}

Конопка Н., Стрихоцький Т. «М'яка сила» в зовнішній політиці Королівства Саудівська Аравія. Політикус. 2020. Вип. 4. С. 100-109. URL: http://politicus.od.ua/4_2020/17.pdf.

Чикризова О. Саудовская модель развития для «мира ислама»: особенности и ограничения. Вестник РУДН. Серия: Международные отношения. 2019. Вып. 19. № 4. С. 545-565.

Alanazi A. Saudi Arabias implementation of soft power policy to confront Irans obvious threats. Monterey, California : Naval Postgraduate School. 2015. 63 p.

Alkatheeri A. \& Khan M. A Perspective on Saudi Soft Power and Cultural Diplomacy. Global Social Sciences Review (GSSR), Vol. IV, No. II, 2019. P. 20-26.

Althari S. Saudi Arabia's cultural renaissance will unleash the Kingdom's creative potential. Al Arabiya. 13 January 2021. URL: https://english.alarabiya.net/en/views/news/middle-east/2021/01/13/Saudi-Arabias-cultural-renaissance-will-unleash-the-Kingdom-s-creative-potential.

Annual report 2018. The King Abdullah bin Abdulaziz International Centre for Interreligious and Intercultural Dialogue. 2019. URL: https:/ / www.kaiciid.org/publications-resources/2018-2019-annual-report.

Castelier S. Gulf's megaprojects face delays, reassessment. Saudi Arabia has cut capital expenditure for a number of Vision 2030 projects amid a drop in oil prices and Chinese investment. Will other Gulf states follow suit? Al-Monitor. 15 May 2020. URL: https://www.al-monitor.com/pulse/originals/2020/05/gulfmegaprojects-delays-saudi-arabia-neom-china-kuwait-oman.html\#ixzz6jMZcU8vN.

Chaves A. Saudi Ministry of Culture launches first artist residency in Jeddah. Arts $\mathcal{E}$ Culture. 8 January 2020. URL: https://www.thenational.ae/arts-culture/art/saudi-ministry-of-culture-launches-first-artistresidency-in-jeddah-1.961513.

Cultural Communication. Sultan bin Abdul-Aziz Al Saud Foundation. URL: https://sbaf.org.sa/en/ activities/cultural-communication/.

Daw film competition. Ministry of Culture. 2019. URL: https://engage.moc.gov.sa/film.

Fahy M. Saudi Arabia sets up $\$ 4$ bn fund to develop tourism industry. Debt and equity investment vehicles will support "flagship mixed-use and hospitality development by leading international operators". The National News. 21 June 2020. URL: https://www.thenationalnews.com/business/travel-and-tourism/saudi-arabiasets-up-4bn-fund-to-develop-tourism-industry-1.1036734.

Filmmakers Program. Ministry of Culture. 2020. URL: https:/ / engage.moc.gov.sa/film_talents.

Frankly Speaking: Kingdom needs to inject $\$ 200$ billion into industry, says Saudi Tourism Minister. Arab News. 22 December 2020. URL: https://arab.news/gzven.

Free tourist trips... Saudi Arabia is using beauty and influencers in Instagram to beautify its image. Al Jazeera. 13 October 2019. URL: https://www.aljazeera.net/news/politics/2019/10/13/\%D8\%A7 \% D9\% $84 \%$ D8 \% B3 \% D8 \% B9\% D9\% 88\% D8\% AF\% D9\% 8A \% D8\% A9- \% D9\% 85\% D8 \% A 4 \% D \% AB \% D8 \% B1\% D9\% 88\% D9\% 86- \% D8\% A5\% D9\% 86\% D8\% B3\% D8 \% AA \% D8\% BA \% D8 \% B1 \% D8 \% A7\% D9\% 85$\%$ D8\% $1 \%$ D8\% AD $\%$ D9\% $84 \%$ D8\% A7\%D8\%AA.

Harris G. Saudi Arabia moves ahead with plans for 2021 biennale at historic Ad Diriyah site. The Art Newspaper. 5 June 2020. URL: https://www.theartnewspaper.com/news/saudi-arabia-moves-ahead-with-plans-for2021-biennale-at-historic-ad-diriyah-site.

Heneghan T. U.N. chief says crises show need for interfaith amity. Reuters. 26 November 2012. URL: https:// www.reuters.com/article/ us-religion-interfaith-centre-idUSBRE8AP0TN20121126.

Institute of Cultural Diplomacy. URL: http://www.culturaldiplomacy.org/index.php?en_culturaldiplomacy. Ismaik H. Four reasons why Saudi Arabia's soft power eclipses all others. Al Arabiya. 4 December 2020. URL: https:/ / english.alarabiya.net/en/views/news/middle-east/2020/12/04/Four-reasons-why-Saudi-Arabias-soft-power-eclipses-all-others.

King Fahd Complex for Printing the Holy Quran Distributes 1,230,949 Copies of Religious Publications during the Month of Rabi' Al-Thani. Saudi Press Agency (SPA). 1 September 2020. URL: https://www.spa.gov.sa/ viewstory.php?lang=en\&newsid=2020719.

King Fahd Glorious Quran Printing Complex. URL: https://qurancomplex.gov.sa/kfgqpc/statist/.

King Fahd Glorious Quran Printing Complex. URL: https://www.my.gov.sa/wps/portal/snp/pages/ agencies/agencyDetails/AC130/!ut/p/z0/04_Sj9CPykssy0xPLMnMz0vMAfIjo8zivQIsTAwdDQz9LQwN zQwCnS0tXPwMvYwNDAz0g1Pz9L30o_ArAppiVOTr7JuuH1WQWJKhm5mXlq8f4ehsaGygX5DtHg4AzvD1g!!/.

Laifa Alfaddgh, director general of Saudi Arabia's National Museum. Arab News. 29 December 2020. URL: https://arab.news/766uv.

Ministry of Culture Launches "Cultural Database" Platform SPA. 2 September 2020. URL: https:/ / www.spa.gov.sa/viewfullstory.php?lang=en\&newsid=2128256.

Ministry of Islamic Affairs, Dawah and Guidance. URL: https://www.moia.gov.sa/AboutMinistry/Pages/ AboutMinistry.aspx.

Misk Art Institute. URL: https://miskartinstitute.org/about. 
Mogielnicki R. "Yes We Cannes": Cinematic Diversification in Saudi Arabia. The Arab Gulf State Institute Washington. 5 June 2018. URL: https://agsiw.org/yes-we-cannes-cinematic-diversification-in-saudi-arabia/. New spaces for Islamic art opened at the Louvre Museum in Paris. Art \& Culture. 15 September 2019. URL: https:/ / www.thenational.ae/arts-culture/art/new-spaces-for-islamic-art-opened-at-the-louvre-museum-inparis-1.909817.

Our Cultural Vision for the Kingdom of Saudi Arabia. March 2019. URL: https://www.moc.gov.sa/themes/ custom/moc/assets/pdf/MOC_Cultural_Vision_EN_NEW.pdf.

Pajtinka E. Cultural diplomacy in theory and practice of contemporary international relations. Politické vedy. 2014. Roč. 17, č. 4, S. 95-108. URL: https://www.researchgate.net/publication/269763112_Cultural_ Diplomacy_in_Theory_and_Practice_of_Contemporary_International_Relations.

Prince Sultan Program for Arabic Language (UNESCO). Sultan bin Abdul-Aziz Al Saud Foundation. URL: https://sbaf.org.sa/en/sultan-program-to-support-education/.

Radwan R., Tashkandi H. Saudi Culture Ministry to offer residency for international artists. Arab News. 27 March 2019. URL: https://www.arabnews.jp/en/arts-culture/article_1334/.

Sallam E. (2018). Saudi Arabia's public diplomacy builds international bridges. Saudi Gazette. URL: https:/ / saudigazette.com.sa/article/545297/Opinion/OP-ED/Saudi-Arabias-public-diplomacy-buildsinternational-bridges.

Sallam E. Saudi Arabia's public diplomacy builds international bridges. Saudi Gazette. 11 October 2018. URL: https:/ / saudigazette.com.sa/article/545297/Opinion/OP-ED/Saudi-Arabias-public-diplomacy-buildsinternational-bridges.

Saudi Arabia commits US\$25 million to UNESCO for the protection of heritage. URL: https://en.unesco.org/ news/saudi-arabia-commits-us25-million-unesco-protection-heritage.

Saudi Arabia opens entry for cultural ideas contest. Arab News. 30 December 2020. URL: https://arab.news/ paeym.

Saudi Arabia to invest \$64bn in entertainment. BBC News. 22 February 2018. URL: https://www.bbc.com/ news/ world-middle-east-43152289.

Saudi Cultural office in Vienna hosts student workshop on moderation. SPA. 28 April 2019. URL: https:// www.spa.gov.sa/viewstory.php?lang=en\&newsid=1917966.

Saudi Culture Minister lauds Cabinet approval of Cultural Development Fund. Arab News. 7 January 2021. URL: https://arab.news/9fwdd.

Saudi Culture Ministry to launch second Art Residency program. Arab News. 28 December 2020. URL: https:/ / arab.news/mtmgc.

Saudi Film Commission launches 28 projects with Daw competition winners. Arab News. 21 January 2021. URL: https://www.arabnews.com/node/1796001/saudi-arabia.

Saudi Pavilion at Cairo International Book Fair Receives Visitors. SPA. 22 January 2019. URL: https://www. spa.gov.sa/viewstory.php?lang=en\&newsid=1877253.

Saudi-directed film "Scales" wins Verona award at Venice Film Festival. Arab News. 8 September 2019. URL: https:/ / www.arabnews.com/node/1551446/lifestyle

Snell J. Religion and policy collide in Saudi-hosted interfaith forum. Al-Monitor. 15 October 2020. URL: https:/ / www.al-monitor.com/pulse/originals/2020/10/saudi-arabia-faith-policy-riyadh-religion-g20united-nations.html\#ixzz6jMS3cNKl.

Steps underway to boost Saudi art, cultural contribution to GDP. Arab News. 10 January 2020. URL: https:// arab.news/rmzzx.

Tashkandi H. Madinah-based calligraphy centre named after Saudi crown prince. Arab News. 28 April 2020. URL: https://arab.news/jbgt7.

The Ministry of Culture. URL: https:/ / www.moc.gov.sa/en/ About.

The Museum of Islamic Art Berlin. Alwaleed Philanthropies. URL: https://alwaleedphilanthropies.org/en/ projects/museum-islamic-art-berlin.

Umińska-Woroniecka, A. Cultural diplomacy in international relations theory and studies on diplomacy. Aктуальні проблеми міжнародних відносин. Вип. 127. Ч. 2, С. 4-19. 2016. URL: http:/ / apir.iir.edu.ua/index.php/ apmv/article/view/3008/2698.

Umrah pilgrimage resumes in Saudi Arabia after 7-month pause. Al-Monitor. 5 October 2020. URL: https:/ / www.al-monitor.com/pulse/originals/2020/10/saudi-arabia-umram-pilgrims-return-grandmosque-mecca-covid.html\#ixzz6jMIXOSqz.

Works by first recipients of Saudi Misk Art Grant go on show. Arab News. 15 December 2020. URL: https://arab.news/yd52f.

\section{References}

Alanazi, A. (2015). Saudi Arabias implementation of soft power policy to confront Irans obvious threats. Monterey, California: Naval Postgraduate School. 63 p. 
Alkatheeri, A. \& Khan, M. (2019). A Perspective on Saudi Soft Power and Cultural Diplomacy, Global Social Sciences Review (GSSR), Vol. IV, No. II, pp. 20-26.

Althari, S. (2021). Saudi Arabia's cultural renaissance will unleash the Kingdom's creative potential. Al Arabiya. Retrieved from: https://english.alarabiya.net/en/views/news/middle-east/2021/01/13/Saudi-Arabia-s-cultural-renaissance-will-unleash-the-Kingdom-s-creative-potential (Last accessed: 12 December 2020).

Annual report 2018. (2019). The King Abdullah bin Abdulaziz International Center for Interreligious and Intercultural Dialogue. Retrieved from: https://www.kaiciid.org/publications-resources/2018-2019-annual-report (Last accessed: 22 January 2021).

Castelier, S. (2020). Gulf's megaprojects face delays, reassessment. Saudi Arabia has cut capital expenditure for a number of Vision 2030 projects amid a drop in oil prices and Chinese investment. Will other Gulf states follow suit? Al-Monitor. Retrieved from: https://www.al-monitor.com/pulse/originals/2020/05/gulf-megaprojects-delays-saudi-arabia-neom-china-kuwait-oman.html\#ixzz6jMZcU8vN (Last accessed: 12 March 2021).

Chaves, A. (2020). Saudi Ministry of Culture launches first artist residency in Jeddah. Arts \& Culture. Retrieved from: https://www.thenational.ae/arts-culture/art/saudi-ministry-of-culture-launches-first-artist-residency-in-jeddah-1.961513 (Last accessed: 7 December 2020).

Chikrizova, O. (2019). Saudovskaya model razvitiya dlya "mira islama": osobennosti i ogranicheniya (The Saudi Model of Development for "Islamic World": The Peculiarities and Limits), Vestnik RUDN. Seriya: Mezhdunarodnyie otnosheniya. Vyip. 19. No. 4. S. 545-565 [in Russian].

Cultural Communication. Sultan bin Abdul-Aziz Al Saud Foundation. Retrieved from https://sbaf.org.sa/ en/activities/cultural-communication/ (Last accessed: 13 December 2020).

Daw film competition (2019). Ministry of Culture. Retrieved from: https://engage.moc.gov.sa/film (Last accessed: 12 December 2020).

Fahy, M. (2020). Saudi Arabia sets up $\$ 4 \mathrm{bn}$ fund to develop tourism industry. Debt and equity investment vehicles will support "flagship mixed-use and hospitality development by leading international operators", The National News. Retrieved from: https:/ / www.thenationalnews.com/business/travel-and-tourism/saudiarabia-sets-up-4bn-fund-to-develop-tourism-industry-1.1036734 (Last accessed: 13 December 2020).

Filmmakers Program (2020). Ministry of Culture. Retrieved from: https://engage.moc.gov.sa/film_talents (Last accessed: 14 December 2020).

Frankly Speaking: Kingdom needs to inject \$200 billion into industry, says Saudi Tourism Minister (2020). Arab News. Retrieved from: https:/ / arab.news/gzvcn (Last accessed: 12 January 2020).

Free tourist trips... Saudi Arabia is using beauty and influencers in Instagram to beautify its image (2019). Al Jazeera. Retrieved from: https://www.aljazeera.net/news/politics/2019/10/13/\%D8\%

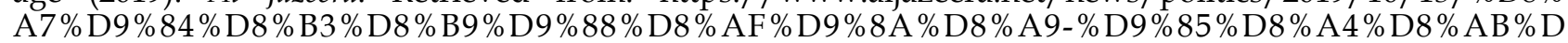
8\%B1\%D9\% 88\% D9\% 86- \% D8\% A5\%D9\% 86\% D8\% B3\%D8\%AA\%D8\%BA\% D8 \% B1\% D8 \% A7\% D9\% 85\%D8\%B1\%D8\%AD\%D9\%84\%D8\%A7\%D8\%AA (Last accessed: 6 December 2020).

Harris, G. (2020). Saudi Arabia moves ahead with plans for 2021 biennale at historic Ad Diriyah site. The Art Newspaper. Retrieved from: https://www.theartnewspaper.com/news/saudi-arabia-moves-ahead-withplans-for-2021-biennale-at-historic-ad-diriyah-site (Last accessed: 3 December 2020).

Heneghan, T. (2012). U.N. chief says crises show need for interfaith amity. Reuters. Retrieved from: https:// www.reuters.com/article/us-religion-interfaith-center-idUSBRE8AP0TN20121126 (Last accessed: 3 March 2020).

Institute of Cultural Diplomacy. Retrieved from: http://www.culturaldiplomacy.org/index.php?en_culturaldiplomacy (Last accessed: 15 December 2020).

Ismaik, H. (2020). Four reasons why Saudi Arabia's soft power eclipses all others. Al Arabiya. Retrieved from: https://english.alarabiya.net/en/views/news/middle-east/2020/12/04/Four-reasons-why-Saudi-Arabias-soft-power-eclipses-all-others (Last accessed: 15 January 2021).

King Fahd Complex for Printing the Holy Quran Distributes 1,230,949 Copies of Religious Publications during the Month of Rabi' Al-Thani. (2020). Saudi Press Agency (SPA). Retrieved from: https:/ / www.spa.gov.sa/ viewstory.php?lang=en\&newsid=2020719 (Last accessed: 15 December 2020).

King Fahd Glorious Quran Printing Complex. Retrieved from: https:/ qurancomplex.gov.sa/kfgqpc/statist/ (Last accessed: 3 March 2020).

King Fahd Glorious Quran Printing Complex. Retrieved from: https://www.my.gov.sa/wps/portal/snp/ pages/agencies/agencyDetails/AC130/!ut/p/z0/04_Sj9CPykssy0xPLMnMz0vMAfIjo8zivQIsTAwdDQz9LQwNzQwCnS0tXPwMvYwNDAz0g1Pz9L30o_ArAppiVOTr7JuuH1WQWJKhm5mXlq8f4ehsaGygX5DtHg4Az-vD1g!!/ (Last accessed: 3 March 2020).

Konopka, N. \& Strykhotskyi, T. (2020). "Miaka syla" v zovnishnii politytsi Korolivstva Saudivska Araviia. ("Soft Power" in the Foreign Policy of the Kingdom of Saudi Arabia). Politykus. Vyp. 4, pp. 100-109. Retrieved from: http:// politicus.od.ua/4_2020/17.pdf [in Ukrainian] (Last accessed: 3 November 2020).)

Laifa Alfaddgh, director general of Saudi Arabia's National Museum. (2020). Arab News. Retrieved from: https:/ /arab.news/766uv (Last accessed: 3 March 2021). 
Ministry of Culture Launches "Cultural Database" Platform (2020). SPA. Retrieved from: https://www.spa. gov.sa/viewfullstory.php?lang=en\&newsid=2128256 (Last accessed: 3 March 2021).

Ministry of Islamic Affairs, Dawah and Guidance. Retrieved from: https://www.moia.gov.sa/AboutMinistry/Pages/AboutMinistry.aspx (Last accessed: 10 March 2021).

Misk Art Institute. Retrieved from: https:/ / miskartinstitute.org/about (Last accessed: 3 December 2020).

Mogielnicki, R. (2018). "Yes We Cannes": Cinematic Diversification in Saudi Arabia. The Arab Gulf State Institute Washington. Retrieved from: https://agsiw.org/yes-we-cannes-cinematic-diversification-in-saudi-arabia/ (Last accessed: 9 March 2021).

New spaces for Islamic art opened at the Louvre Museum in Paris (2019). Art \& Culture. Retrieved from: https://www.thenational.ae/arts-culture/art/new-spaces-for-islamic-art-opened-at-the-louvre-museum-inparis-1.909817 (Last accessed: 3 December 2020).

Our Cultural Vision for the Kingdom of Saudi Arabia. (2019). Retrieved from: https://www.moc.gov.sa/ themes/custom/moc/assets/pdf/MOC_Cultural_Vision_EN_NEW.pdf (Last accessed: 17 December 2020).

Pajtinka, E. (2014). Cultural diplomacy in theory and practice of contemporary international relations. Politické vedy. Roč. 17, č. 4, 95-108. Retrieved from: https://www.researchgate.net/publication/269763112_Cultural_Diplomacy_in_Theory_and_Practice_of_Contemporary_International_Relations (Last accessed: 21 January 2021).

Prince Sultan Program for Arabic Language (UNESCO). Sultan bin Abdul-Aziz Al Saud Foundation. Retrieved from: https://sbaf.org.sa/en/sultan-program-to-support-education/ (Last accessed: 11 February 2021).

Radwan, R. \& Tashkandi H. (2019). Saudi Culture Ministry to offer residency for international artists. Arab News. Retrieved from: https://www.arabnews.jp/en/arts-culture/article_1334/ (Last accessed: 2 February 2021).

Sallam, E. (2018). Saudi Arabia's public diplomacy builds international bridges. Saudi Gazette. Retrieved from: https:// saudigazette.com.sa/article/545297/Opinion/OP-ED/Saudi-Arabias-public-diplomacy-builds-international-bridges (Last accessed: 5 March 2021).

Saudi Arabia commits US\$25 million to UNESCO for the protection of heritage. Retrieved from: https:// en.unesco.org/news/saudi-arabia-commits-us25-million-unesco-protection-heritage (Last accessed: 3 December 2020).

Saudi Arabia opens entry for cultural ideas contest (2020). Arab News. Retrieved from: https://arab.news/ paeym (Last accessed: 16 January 2021).

Saudi Arabia to invest \$64bn in entertainment (2018). BBC News. Retrieved from: https://www.bbc.com/ news/world-middle-east-43152289 (Last accessed: 30 January 2021).

Saudi Cultural office in Vienna hosts student workshop on moderation (2019). SPA. Retrieved from: https:// www.spa.gov.sa/viewstory.php?lang=en\&newsid=1917966 (Last accessed: 16 December 2020).

Saudi Culture Minister lauds Cabinet approval of Cultural Development Fund. (2021). Arab News. Retrieved from: https://arab.news/9fwdd (Last accessed: 6 March 2021).

Saudi Culture Ministry to launch second Art Residency program (2020). Arab News. Retrieved from: https://arab.news/mtmgc (Last accessed: 12 January 2021).

Saudi Film Commission launches 28 projects with Daw competition winners (2021). Arab News. Retrieved from: https:// www.arabnews.com/node/1796001/saudi-arabia (Last accessed: 8 January 2021).

Saudi Pavilion at Cairo International Book Fair Receives Visitors. (2019). SPA. Retrieved from: https:/ / www.spa.gov.sa/viewstory.php?lang=en\&newsid=1877253 (Last accessed: 6 December 2020).

Saudi-directed film "Scales" wins Verona award at Venice Film Festival. (2019). Arab News. Retrieved from: https://www.arabnews.com/node/1551446/lifestyle (Last accessed: 16 November 2020).

Snell, J. (2020). Religion and policy collide in Saudi-hosted interfaith forum. Al-Monitor. Retrieved from: https://www.al-monitor.com/pulse/originals/2020/10/saudi-arabia-faith-policy-riyadh-religion-g20-united-nations.html\#ixzz6jMS3cNKl (Last accessed: 17 December 2020).

Steps underway to boost Saudi art, cultural contribution to GDP (2020). Arab News. Retrieved from: https://arab.news/rmzzx (Last accessed: 16 January 2021).

Tashkandi, H. (2020a). Madinah-based calligraphy centre named after Saudi crown prince. Arab News. Retrieved from: https:/ / arab.news/jbgt7 (Last accessed: 16 January 2021).

Tashkandi, H. (2020b) World-class calligraphers supervise new online course. Arab News. Retrieved from: https://www.arabnews.com/node/1665956/saudi-arabia (Last accessed: 9 December 2020).

The Ministry of Culture. Retrieved from: https://www.moc.gov.sa/en/About. (Last accessed: 16 January 2021).

The Museum of Islamic Art Berlin. Alwaleed Philanthropies. Retrieved from: https://alwaleedphilanthropies. org/en/projects/museum-islamic-art-berlin (Last accessed: 16 January 2021).

Umińska-Woroniecka, A. (2016). Cultural diplomacy in international relations theory and studies on diplomacy. Aktualni problemy mizhnarodnykh vidnosyn. Vyp. 127. Ch. 2, pp. 4-19. Retrieved from: http:/ /apir.iir.edu.ua/ index.php/apmv/article/view/3008/2698 (Last accessed: 1 December 2020). 
Umrah pilgrimage resumes in Saudi Arabia after 7-month pause (2020). Al-Monitor. Retrieved from: https:// www.al-monitor.com/pulse/originals/2020/10/saudi-arabia-umram-pilgrims-return-grand-mosque-mecca-covid.html\#ixzz6jMIXOSqz (Last accessed: 10 January 2021).

Works by first recipients of Saudi Misk Art Grant go on show (2020). Arab News. Retrieved from: https://arab.news/yd52f (Last accessed: 25 January 2021).

\section{Summary}

Konopka N. O., Strykhotskyi T. L. Cultural diplomacy of the Kingdom of Saudi Arabia in the context of the Vision 2030 strategy implementation. - Article.

In recent years, increased attention has been paid to the growing role of soft power as well as public and cultural diplomacies in international relations. This article is devoted to the analysis of the peculiarities of Saudi Arabia's cultural diplomacy in the context of the Vision 2030 strategy implementation.

Riyadh sees cultural diplomacy as an important tool to improve its international image and develop strategic communication. The strategies Vision 2030 (2017) and Cultural Vision (2019) are the framework documents of the Kingdom on the basis of which it is possible to analyze its soft power policy.

The authors trace different levels of cultural development in Saudi Arabia. The status of the KSA, as the centre of Islam, allows the active use of religion as one of the most important components of cultural diplomacy. The same reason permits the development of religious tourism. The Ministry of Islamic Affairs, Dawah and Guidelines promotes the teachings of the Quran, develops Islamic centres and mosques, coordinates Islamic organizations, supports Islamic universities and institutes abroad, and strengthens the reputation of the state and Saudi rulers as Custodians of the Two Mosques.

In recent years, the Kingdom has undergone major reforms, including the cultural ones. The authors outline how Saudi Arabia has intensified cultural policy in implementing its Vision 2030 strategy through the establishment of the Ministry of Culture, the MiSK Art Institute and other organization s.

The authors conclude that cultural diplomacy is attractive to the country's leadership as a tool for disseminating Saudi values and that pandemic will determine the further framework for the development of Saudi cultural diplomacy in the nearest future.

Key words: Kingdom of Saudi Arabia (KSA), cultural diplomacy, Vision 2030, Cultural Vision, Ministry of Culture, Islam, book printing, tourism, MiSK Art Institute.

\section{Анотація}

Конопка Н. О., Стрихоцъкий Т. Л. Культурна дипломатія Королівства Саудівська Аравія в реалізації стратегіï “Vision 2030". - Стаття.

Упродовж останніх років усе більша увага прикута до питання вивчення збільшення ролі «м'якої сили» у міжнародних відносинах, публічної дипломатії та культурної дипломатії зокрема. Стаття присвячена аналізу особливостей культурної дипломатії Королівства Саудівська Аравія (КСА) в контексті реалізації стратегії "Vision 2030".

Офіційний Ер-Ріяд вбачає у культурній дипломатії важливий чинник покращення міжнародного іміджу та розвитку стратегічних комунікацій. Основоположними документами Королівства, на основі яких можна проаналізувати складники його політики “м'якої сили», є стратегії “Vision 2030” (2017р.) i "Cultural Vision" (2019 p.).

Простежено різні рівні розвитку культурної сфери у Саудівській Аравії. Статус КСА як центру світового ісламу дозволяе активно використовувати релігію як одну з найголовніших складових частин культурної дипломатії. Ця ж причина уможливлює розвиток релігійного туризму. Міністерство у справах ісламу, заклику і настанов популяризує вчення Корану, розвиває ісламські центри та мечеті, координує діяльність ісламських організацій, підтримує ісламські університети та інститути за кордоном, що укріплює репутацію держави та саудівських правителів як хранителів двох святинь.

Протягом останніх років Королівство переживає серйозні реформи, в тому числі й у сфері культури. Автори звертають увагу на те, як Саудівська Аравія активізувала культурну політику в ході реалізації стратегії “Vision 2030” шляхом створення Міністерства культури, Інституту культури МіСК та інших установ та організацій.

Автори дійшли висновку, що культурна дипломатія приваблива для керівництва країни як інструмент поширення саудівських цінностей і саме пандемія визначатиме подальші рамки розвитку культурної дипломатії Саудівської Аравії у найближчому майбутньому.

Ключовi слова: Королівство Саудівська Аравія (KCА), культурна дипломатія, “Vision 2030”, “Cultural Vision", Міністерство культури, іслам, книгодрукування, туризм, Інститут Мистецтва МіСК. 